Book Review Symposium "The portability of care in an increasingly mobile world: Chains, drains and circulation"

\title{
Comment 3: Widening the Scope and Moving Beyond Care Chains
}

\author{
Pierrette Hondagneu-Sotelo \\ University of Southern California \\ sotelo@usc.edu
}

\begin{abstract}
This symposium offers a critical discussion of the logics and dynamics behind the new 'care circulation' perspective offered by Loretta Baldassar and Laura Merla in their edited volume entitled "Transnational Families, Migration and the Circulation of Care". This contribution highlights the richness of this new framework, and sets out some key issues that have not yet been fully addressed in the study of caregiving in the age of global migration, such as the need to 'bring back' the body and the materiality of care in our conceptualization of transnational practices of care.
\end{abstract}

Keywords: gender; transnational families; circulation of care; mobility; body

Resumen. Comentario 3. Ampliar las posibilidades más allá de las "cadenas globales»

Este simposio ofrece una discusión crítica de las lógicas y dinámicas en torno a la nueva perspectiva de la "circulación del cuidado" presentadas por Loretta Baldassar y Laura Merla en su volumen titulado Transnational Families, Migration and the Circulation of Care. El comentario subraya la riqueza de este nuevo marco conceptual y propone algunos temas clave que todavía no han sido plenamente abordados en el estudio del cuidado en la era de la migración global, tales como la necesidad de «recuperar» el cuerpo y la materialidad del cuidado en nuestra conceptualización de las prácticas de cuidado transnacionales.

Palabras clave: género; familias transnacionales; circulación del cuidado; movilidad; cuerpo 
I sometimes feel as though we have collectively stepped into a vortex of constant motion, where continual mobility, movement and flows reign. Vertigo may be the malady of the epoch. Certainly the intensified pace of daily life and new innovations in telecommunications, and the commodification of new services and products help put us into that space of flows.

Transnational Families, Migration and the Circulation of Care seeks to move us from the stagnant swamp of transnational care chains-and the prescription of focusing primarily on migrant domestic worker women in the global north and their dilemmas of motherhood as they seek to care and provide for their kids - towards recognition and analysis of a broad array of complex, interlocking relations of family care. In this valuable book, editors Loretta Baldassar and Laura Merla have compiled a rich selection of readings that examine transnational family relationships and their permutations of care. Care extends beyond mother-child dyads, beyond nuclear family forms, and beyond nation-state boundaries, so that attention is now deservedly directed towards an array of reciprocal and asymmetrical exchanges within transnational family networks. Mobility and absence are now common features of family life, the editors remind us, and far more people than just mothers and their children are involved in this swirl. Proximity now appears as a requirement of the past, if it was one at all.

The care circulation lens is a welcomed addition to transnational motherhood and care chains, redirecting our gaze to the myriad of practices and processes that bind together transnational families around the globe. Part of their goal is to destigmatize transnational families, to question the inherent deviance or second-class status of family care that occurs from afar.

A common complaint voiced about edited volumes in general is that the essays do not cohere. That is certainly not the case with this book. The case studies and selections offered by various authors fit the framework. The selections are too rich and diverse to describe in totality, so here is a slice of what the book holds.

Karin Wall and Claudio Bolzman call attention to the diversity of care experienced during the life course, showing how aging transitions us into different care arrangements and expectations. Majella Kilkey's work on Polish handymen in London prompts us to add men and fathers into the equation of transnational care, emphasizing that these men seek to broaden their practices and pleasures of fatherhood beyond just one-dimensional breadwinning. Marina Ariza offers a comparison of care circulation among Mexican and Dominican families, and wisely cautions us from overemphasizing dynamics of harmonious reciprocity. Paola Bonizzoni and Paolo Boccagni bring intersectional analysis of gender, legal status and social class to the fore. I particularly appreciated the attention to transnational caregiving among professional class and middle class immigrants offered by Loretta Baldassar and Raelene Wilding. We know that it is difficult to "study up" the class hierarchy, and I think this is a very promising line of research, particularly with so many affluent transnational families seeking to maximize educational opportunities and 
privileges for their children. There are more gems in this book too, too much to detail in these short pages.

The care circulation perspective offered in this book is a useful extension of the care chain approach. That's how scholarship progresses, by relying on prior research and theoretical paradigms as building blocks to make something new. In the spirit of collegial dialogue and moving forward, I have a few suggestions for where we might look next in the quest to understand caregiving in the contemporary age of global migration.

First, I believe we need to bring back the body. Global and transnational processes involve corporeal reconfigurations of care, so I think we need to bring in an analysis of care as an embodied dynamic in transnational circulation. This might include inquiries into how bodies are situated in transnational circulation of care, including reproduction (very pertinent in the age of transnational commodified surrogacy). Also, we should consider the nitty gritty of caring and cleaning both young and aging bodies and the variously abled ones too, as well as the body in the work of hugging, feeding, bathing, cooking, and gifting. Caring involves the heart and the back. What is the toll that this takes? There's lots of interesting work on embodiment today, but the transnational caregiving literature has emphasized emotions and circulation, and most of the literature does not grapple with how embodiment is situated in transnational care. Physical absence and mobility of the transnational migrant body requires that we look at those bodies that remain too, as well as those caring and being cared for in new places.

Secondly, we might focus more on place and the materiality of transnational family care. Even when mediated by telecommunications technology and social media, care is still happening on earth. In the introduction, editors Baldassar and Merla are fully cognizant of this and remind us that "transnational family members are located in particular places at particular times, and their caregiving practices are various affected by this 'territorialization'..." (p. 21) But the essays and the book in general, I felt, emphasized flows, deterritorialization and circulation over concrete caring practices and places where care occurs, places such as homes, kitchens, bedsides, schools, neighborhoods, nations.

Thirdly, we should be asking about self-care of those who carry the strongest load of care for transnational family members. The authors and editors of this volume wish to destigmatize transnational mothers and others, but the fact remains that in many contexts, they-almost always women-face criticism and stress. How do they care for themselves on a daily basis? How do they care for themselves emotionally and physically? Are there particular practices, therapies, desires and fantasies that make participation in the transnational care circuit bearable, or even pleasurable? This would be particular important in situations where possibilities for travel and circulation are severely restricted, or where there is strong normative disapproval.

Fourthly, the next phase of research might highlight the agency and subjectivity of those who are cared for in transnational family circuits. Children, 
the elderly, and the physically less abled are not simply passive in these interactions. And along those lines, I think we need to consider the special place of children and youth. In many immigrant and transnational migrant families, children serve as critical generators of family resources and income, as mediators and translators, and we might ask how this tips the balance of power and caregiving in families.

This is a valuable volume that extends the analysis of transnational care work so that we recognize the formation of fluid webs and circuits of transnational care. It helps us understand social processes that are today occurring on every continent. No doubt it will provide a nudge for developing appropriately transnational policy reforms, and it will certainly stimulate more excellent research on this topic. 